\title{
Training cardiothoracic surgeons of the future: The UK experience
}

Louise Kenny, MBBS, MRCS, MED, ${ }^{a}$ Karen Booth, MBBS, FRCS (C-Th), MED,

Kathrin Freystaetter, MD, ${ }^{a}$ Greta Wood, MRes, ${ }^{\mathrm{b}}$ Gary Reynolds, MBBS, MRCP, PhD, ${ }^{\mathrm{b}}$

Sridhar Rathinam, MBBS, FRCS $(\mathrm{C}-\mathrm{Th}){ }^{\mathrm{c}}$, and Narain Moorjani, MB ChB, MD, FRCS (C-Th)

\section{ABSTRACT}

Objective: The study aimed to assess targeted simulation courses, including live animal operating, as complementary training tools with regard to 2 key surgical skills in early cardiothoracic surgeon training.

Methods: Twenty UK surgical trainees (equivalent to cardiothoracic surgery resident physicians in the United States) in their first year of residency training were evaluated. Assessment of skills in pulmonary wedge resection and cardiopulmonary bypass were undertaken before and after 2 boot camp-style courses, including live animal operating (boot camp 1 and boot camp 2). Resident performance was evaluated by surgical trainers using objective structured assessment of technical skills matrices. Trainers completed a survey on skill development and trainer confidence in the trainee precourse and postcourse.

Results: Trainee assessment scores pre- and postcourses were analyzed using a 2tailed Wilcoxon signed-rank test demonstrating a significant improvement in trainee performance in boot camp 1 in performing cardiopulmonary bypass (median score, 21 precourse and 28 postcourse; $P=.001$ ) and pulmonary wedge resection (median score, 25 precourse and 32 postcourse; $P=.012$ ), and in boot camp 2 , in performing cardiopulmonary bypass (median score, 28 precourse and 30.5 postcourse; $P=.018$ ) and pulmonary wedge resection (median score, 31.5 precourse and 37 postcourse; $P=.018$ ). Trainers reported increased confidence and decision-making competency of residents and increased confidence of trainers to allow more participation in management. It was found that $83.3 \%$ of trainers would support trainee attendance in subsequent years.

Conclusions: Live animal operating as a component of targeted cardiothoracic surgery skill training courses significantly improves technical skills, builds confidence of surgical trainers in resident physicians' practice, and should be supported

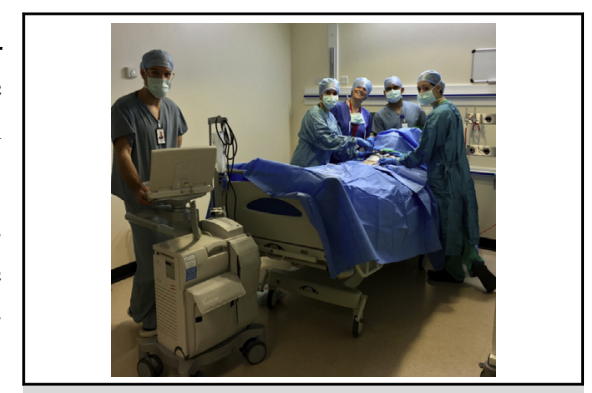

Louise Kenny, MBBS, MRCS, MED, with boot camp participants.

\section{Central Message}

Targeted skill training utilizing live animal operating as part of boot camp-style courses is an effective tool that improves technical performance in future cardiothoracic surgeons.

\section{Perspective}

This study explores the utility and influence of structured curriculum-targeted surgical courses in light of current training challenges. Live animal operating safely facilitates training of the current generation of trainees in a controlled environment with positive implications for patient care in the operating room.

See Editorial Commentary page 2539. by the surgery community. (J Thorac Cardiovasc Surg 2018;155:2526-38)

Cardiothoracic surgeon training is facing multifactorial challenges and establishing safe and effective training

\footnotetext{
From the ${ }^{\mathrm{a} D e p a r t m e n t}$ of Cardiothoracic Surgery, Freeman Hospital, Newcastle Upon Tyne, United Kingdom; ${ }^{b}$ Faculty of Medical Sciences, Newcastle University, Newcastle Upon Tyne, United Kingdom; ${ }^{c}$ Department of Thoracic Surgery, Glenfield Hospital, Leicester, United Kingdom; and ${ }^{\mathrm{d}}$ Department of Cardiothoracic Surgery, Papworth Hospital, Cambridge, United Kingdom.

Read at the 97th Annual Meeting of The American Association for Thoracic Surgery, Boston, Massachusetts, April 29-May 3, 2017.

Received for publication April 7, 2017; revisions received Jan 15, 2018; accepted for publication Jan 26, 2018; available ahead of print April 13, 2018.

Address for reprints: Louise Kenny, MBBS, MRCS, MED, Department of Cardiothoracic Surgery, Freeman Hospital, Freeman Rd, Newcastle Upon Tyne NE7 7DN, United Kingdom (E-mail: Lkenny@ doctors.net.uk).

0022-5223/\$36.00

Copyright (c) 2018 by The American Association for Thoracic Surgery

https://doi.org/10.1016/j.jtcvs.2018.01.088
}

pathways is paramount. In the United Kingdom, particular challenges have arisen due to reduced exposure of residents to operating rooms as a consequence of the European Working Time Directive alongside publication of surgeonspecific mortality data.

UK residents in their first year of training are greatly varied in experience in the specialty, meaning they possess

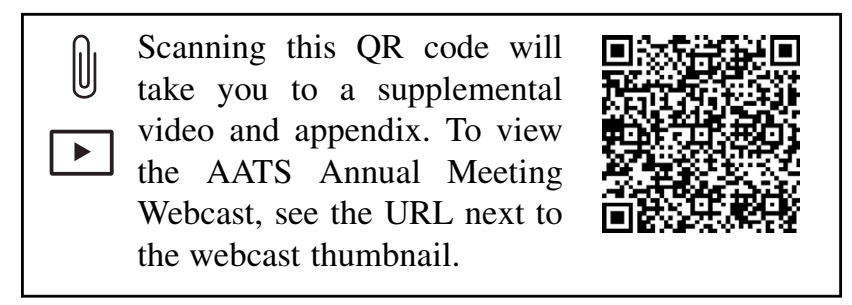




\section{Abbreviations and Acronyms \\ $\mathrm{CPB}=$ cardiopulmonary bypass \\ OSATS $=$ objectively structured assessment of technical skills \\ LAO = live animal operating \\ PWR = pulmonary wedge resection}

mixed skill levels and baseline knowledge. Standardization of resident education has driven the establishment of training courses. This motivated the commissioning and evaluation of a course involving live animal operating (LAO) targeting 2 key early skills: pulmonary wedge resection (PWR) and management of a patient on cardiopulmonary bypass $(\mathrm{CPB})$.

\section{BACKGROUND}

Cardiothoracic training in the United Kingdom requires a total of 10 years following medical school. Trainees (also known as residents) must annually gain enough experience to meet the curriculum competencies required to progress toward consultancy. Each year a limited number of residencies are offered nationally. In 2017, just 8 posts were offered across the United Kingdom. Currently, there are fewer than 200 British surgeons who are in the challenging position of trying to become the cardiothoracic surgeons of the future.

\section{COURSE DESIGN}

The courses in the first training year serve as an introduction to specialty training in cardiothoracic surgery, including performing appropriate technical skills, important aspects of intensive care management, and practice of surgical access.

Boot camp 1 is a 3-day course in the United Kingdom utilizing simulation-based techniques, including low-fidelity, low-cost synthetic simulators; high-fidelity computerized simulators; and cadaveric or animal tissue-based wet-lab simulation models. Core knowledge and the principles of surgical techniques are taught through interactive small group (usually 4 participants or fewer) sessions.

Boot camp 2 takes place in Germany over 3 days and offers the opportunity for live animal operating simulation models in a fully-kitted operating room, including anesthetist, perfusionist, bypass pump, scrub team, and all equipment. Administering cardiopulmonary bypass and performing a pulmonary wedge resection are possible on anesthetized pigs in a full operating room.

FIGURE 1. Structural design of the courses.
The Society for Cardiothoracic Surgery in Great Britain and Ireland introduced boot camp to address the variance in clinical knowledge, competence, and skills of appointed residents. ${ }^{1}$ A portfolio of 12 structured courses was designed to complement in-work training with relevant content to the level of program. Structural design of the courses is detailed in Figure 1. The portfolio, which starts with boot camp and culminates in a preconsultant course, was developed in collaboration with the Speciality Advisory Committee to the Royal College of Surgeons, and is funded by educational grants from industry, permitting free attendance for trainees since 2013. ${ }^{1}$ The flow of a trainee through the first year of in-work training, clinical supervision, assessment, and boot camp is demonstrated in Figure 2.

In the realm of patient outcome reporting, the literature favors surgeons-in-training performing even highly complex procedures under supervision. ${ }^{2}$ However, patients undergoing cardiac surgery carry a higher risk profile, offering a challenging training substrate. Furthermore, complex cases occur at a frequency that limits trainee exposure. Additionally, many programs have to deal with a reduction in working hours. ${ }^{3,4}$ Although training-focused programs increase exposure, ${ }^{3}$ these limitations reduce training opportunities.

Ericsson's theory of sustained deliberate practice, often applied to sportsmen, chess players, and surgeons alike, indicates thousands of practice hours are necessary to reach high performance levels. Repetitive skill practice with purposeful, directed feedback loops guide improvement. This is a pipe dream when considering time and safety pressures and intervals between training opportunities in operating rooms. ${ }^{5}$

Structured training courses are independent of chance encounters of the complex and unusual, remove detriment to patient safety, and are an opportunity to deliver standardized education. Cardiothoracic surgery reflects the boom in the simulation trade, with both sides of the Atlantic involved in boot camps that allow application of knowledge in a safe environment where mistakes can be made without consequence. ${ }^{6,7}$ Focusing on a defined task and repeated practice, along with coaching and feedback on performance, is the foundation of these courses, and an important determinant in the success of boot camps. ${ }^{8}$

\section{LAO}

LAO is not commonly used as a routine component of surgical training due to financial, cultural, and ethical considerations. ${ }^{9}$ However, it is well established in other specialties as a high-fidelity simulation promoting psychomotor skills, ${ }^{10}$ communication, hierarchy, leadership, and crisis management. ${ }^{11}$ Kneebone and colleagues ${ }^{12}$ discuss the need for simulation to "mirror the unruliness of life" to achieve realism and LAO offers just this-the highestfidelity training resource that eliminates the concerns of 


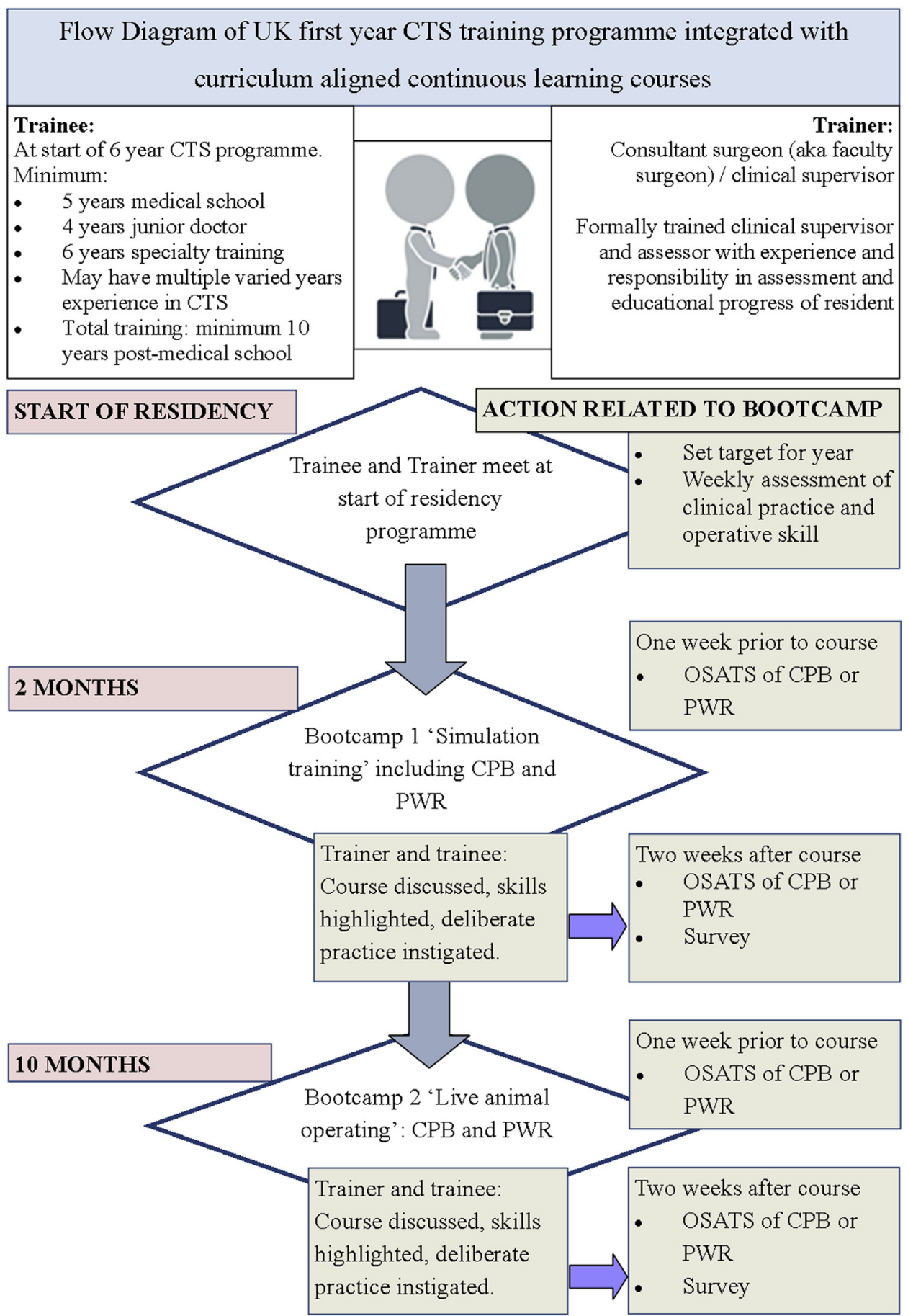

FIGURE 2. The flow through first-year residency for both trainer and trainee adapting to integrated courses aligned with in-work education. CTS, Cardiothoracic surgery; OSATS, objectively structured assessment of technical skills; $C P B$, cardiopulmonary bypass; $P W R$, pulmonary wedge resection.

training in vivo. Animals are draped, undergo operations, and managed in exactly the same manner as a human patient. These animal patients respond in strikingly similar fashion to intervention or crises, allowing precision rehearsal of real life. Understanding, anticipating, and managing risk is part of becoming an expert ${ }^{10}$ and LAO recreates the sensations and reactions to allow development of risk management skills.

In the United States, it is reported that only 2 training units continue to use LAO in surgical clerkships, with the practice being phased out with support from the Physicians Committee for Responsible Medicine. ${ }^{13}$ In the United 
Kingdom, legality is complex and LAO is used primarily within military medical training. LAO provides a unique opportunity to obtain critical skills on a living animal patient in the current challenging climate of training that cannot currently be provided by other simulators.

We hypothesized that targeted simulation courses, including LAO, are effective complementary training tools for the real-world development of surgeons during the first year of training, additionally boosting trainer confidence in the trainee. We sought to evaluate the influence of such courses using objective assessment methods to chart successes and report a reproducible format for other training systems worldwide.

\section{METHODS}

\section{Overview}

In 2015, just 20 doctors in total were appointed to the UK and Irish national training program for cardiothoracic surgery. All 20 first-year residents were recruited and over a 12-month period all attended at least 1 boot camp.

We obtained financial support from industry (Ethicon Inc, Somerville, $\mathrm{NJ}$ ) to allow residents to attend all of the courses free of charge, with registration, accommodation, and travel costs for trainees and faculty covered by an educational grant. Ethicon also provided facilities and equipment.

The utility of the courses was assessed using 2 methods: an objective assessment of resident performance and an evaluation of supervisors' observations. Resident self-assessment and feedback is discussed as the focus another article.

Skill transfer from simulator to operating room remains challenging to demonstrate in a quantitative manner due to the multifactorial nature of surgery, training, and assessment. Although it is an easy assumption to make that improvement on simulator precedes improvement in vivo, it is important to demonstrate the benefit, particularly when funding and justifying LAO. We chose to tackle this difficult assumption with in-theatre assessment.

\section{Method 1: Objective Skills Assessment}

Objectively structured assessment of technical skills (OSATS) (Figure 3) was used for performance assessment in 2 key procedures, $\mathrm{CPB}$ and PWR. ${ }^{14}$ These are standardized forms that the authors modified to be applicable to the skills being assessed. OSATS consists of a taskspecific checklist and a global rating scale utilizing a 5-point Likert scale and have been reported to have high reliability, interrater reliability, and construct validity. ${ }^{15,16}$ OSATS are a validated tool used in the assessment of candidates applying to cardiothoracic surgery residency programs in the United Kingdom. This validated format has been used since 2010 for this purpose under the guidance of a national educational review panel. ${ }^{17}$ Rigorous blueprinting of wording, criteria, and scales from a formally validated OSATS matrix, including those used in the UK national selection process to resident programs for cardiothoracic surgery, was performed by an experienced educationalist (L.K.). ${ }^{15,17}$ Further review of the matrix was undertaken by a second educationalist (K.B.). Alongside the strong basis in the UK Intercollegiate Surgical Curriculum Programme assessment structure, ${ }^{18}$ this allowed development of a robust, albeit invalidated user-friendly tool.

\begin{tabular}{|c|c|c|c|c|c|c|}
\hline STEP & $\mathbf{0}$ & 1 & 2 & 3 & 4 & $\mathbf{5}$ \\
\hline $\begin{array}{l}\text { Appropriate placement of ports } \\
\text { and minimal trauma during port } \\
\text { dissection and insertion }\end{array}$ & $\begin{array}{l}\text { Not able } \\
\text { to do }\end{array}$ & $\begin{array}{l}\text { Tentative or awkward use, poor } \\
\text { view. Bleeding from port site. } \\
\text { Secondary ports not inserted under } \\
\text { direct vision. }\end{array}$ & & $\begin{array}{l}\text { Awkward placement requiring } \\
\text { readjustment, reasonable view, } \\
\text { could be improved. Mild bleeding, } \\
\text { reasonable use of direct vision. }\end{array}$ & & $\begin{array}{l}\text { Good safe placement, confident, } \\
\text { Good view during direct vision. No } \\
\text { bleeding or efficiently dealt with. }\end{array}$ \\
\hline $\begin{array}{l}\text { Use of thoracoscope correctly } \\
\text { to aid identification of lobe } \\
\text { anatomy and pathology } \\
\text { (understanding anatomy) }\end{array}$ & $\begin{array}{l}\text { Not able } \\
\text { to do }\end{array}$ & $\begin{array}{l}\text { Unsure and hesitant identification, } \\
\text { incorrect orientation using scope. }\end{array}$ & & $\begin{array}{c}\text { Partial identification of lobes, } \\
\text { difficulty in identifying pathological } \\
\text { wedge due to poor orientation. }\end{array}$ & & $\begin{array}{l}\text { Good identification of lobes and } \\
\text { pathology, good orientation using } \\
\text { scope. }\end{array}$ \\
\hline $\begin{array}{l}\text { Tissue handling - minimising } \\
\text { trauma to lung tissue using } \\
\text { instruments }\end{array}$ & $\begin{array}{l}\text { Not able } \\
\text { to do }\end{array}$ & $\begin{array}{l}\text { Frequently used unnecessary force } \\
\text { or inappropriate instrument use } \\
\text { causing bleeding or trauma. }\end{array}$ & & $\begin{array}{l}\text { Careful handling of tissue but } \\
\text { occasional inadvertent damage due } \\
\text { to instrument choice or force. }\end{array}$ & & $\begin{array}{l}\text { Consistently handled tissues } \\
\text { appropriately with no damage. } \\
\text { Correct choice of instruments. }\end{array}$ \\
\hline $\begin{array}{l}\text { Orientates and places lung } \\
\text { appropriately for resection }\end{array}$ & $\begin{array}{l}\text { Not able } \\
\text { to do }\end{array}$ & $\begin{array}{l}\text { Poor use of ports to orientate and } \\
\text { present wedge. Hesitant or } \\
\text { awkward orientation and } \\
\text { movements of instruments. }\end{array}$ & & \begin{tabular}{|c|} 
Efficient motion and efficiency, \\
reasonable use of instrument access \\
techniques to orientate and present \\
lung but some unnecessary or \\
damaging moves.
\end{tabular} & & $\begin{array}{c}\text { Maximum efficiency and good use of } \\
\text { instrument orientation to present } \\
\text { lung. }\end{array}$ \\
\hline $\begin{array}{l}\text { Appropriate use of stapling } \\
\text { device }\end{array}$ & $\begin{array}{l}\text { Not able } \\
\text { to do }\end{array}$ & $\begin{array}{l}\text { Awkward and unsure - poor tension } \\
\text { or placement, uncertain or incorrect } \\
\text { firing requiring unnecessary refills. }\end{array}$ & & $\begin{array}{l}\text { Competent use of stapler but with } \\
\text { occasional or incorrect awkward } \\
\text { placement or tension. Safe } \\
\text { adequate firing but some error. }\end{array}$ & & $\begin{array}{l}\text { Appropriate use of stapler, using } \\
\text { required number of refills, } \\
\text { achieving correct placement and } \\
\text { tension with no errors. }\end{array}$ \\
\hline Ensures pneumostasis & $\begin{array}{l}\text { Not able } \\
\text { to do }\end{array}$ & $\begin{array}{l}\text { Does not check lung surface. Poor } \\
\text { use of topical adhesives if required. }\end{array}$ & & $\begin{array}{c}\text { Inadequate checking for } \\
\text { pneumostasis. Occasional or } \\
\text { awkward use of adhesives if } \\
\text { required. } \\
\end{array}$ & & $\begin{array}{l}\text { Clearly checks for pneumostasis } \\
\text { and able to apply topic adhesives if } \\
\text { required. }\end{array}$ \\
\hline $\begin{array}{l}\text { Extraction and demonstration } \\
\text { of pathological lung tissue }\end{array}$ & $\begin{array}{l}\text { Not able } \\
\text { to do }\end{array}$ & $\begin{array}{l}\text { Poor or awkward instrument } \\
\text { handling to extract wedge place in } \\
\text { bag. Damage to wedge. }\end{array}$ & & $\begin{array}{l}\text { Able to handle wedge with } \\
\text { occasional awkward or poor } \\
\text { instrument use to place in bag or } \\
\text { extract. } \\
\end{array}$ & & $\begin{array}{l}\text { Competent handling of wedge and } \\
\text { placement in bag or extraction. }\end{array}$ \\
\hline $\begin{array}{l}\text { Appropriate closure including } \\
\text { drainage of thoracic space }\end{array}$ & $\begin{array}{l}\text { Not able } \\
\text { to do }\end{array}$ & $\begin{array}{l}\text { Hesitant, awkward handling of } \\
\text { sutures and instruments. Incorrect } \\
\text { placement of drain, poor closure. }\end{array}$ & & $\begin{array}{c}\text { Occasional awkward handling of } \\
\text { suture but reasonable competency, } \\
\text { further work required for effective } \\
\text { placement of drain, and adequate } \\
\text { closure. }\end{array}$ & & $\begin{array}{c}\text { Competent use of instruments and } \\
\text { suture to achieve good closure and } \\
\text { drain placement. }\end{array}$ \\
\hline Global Score & & Poor - requires training & & Reasonable & & Excellent \\
\hline
\end{tabular}

FIGURE 3. Objectively structured assessment of technical skills (OSATS) matrices adapted for pulmonary wedge resection (PWR) and cardiopulmonary bypass $(\mathrm{CPB})$, and recognized assessment sources demonstrated global ranking scale. 


\begin{tabular}{|c|c|c|c|c|c|c|}
\hline STEP & 0 & 1 & 2 & 3 & 4 & 5 \\
\hline $\begin{array}{l}\text { Preparation for CPB: } \\
\text { - Assessment of ascending } \\
\text { aorta } \\
\text { - Purse string placement } \\
\text { - Cannulation }\end{array}$ & $\begin{array}{l}\text { Not able } \\
\text { to do }\end{array}$ & $\begin{array}{l}\text { Does not assess for aortic } \\
\text { calcification. Tentative or awkward } \\
\text { placement of purse-string sutures. } \\
\text { Unsafe cannulation. Poor technical } \\
\text { skill. }\end{array}$ & & $\begin{array}{l}\text { Checks for aortic calcification but } \\
\text { cannulation site too low. Awkward } \\
\text { placement requiring readjustment, } \\
\text { reasonable and safe technical skills } \\
\text { but could be improved. }\end{array}$ & & $\begin{array}{l}\text { Checks for aortic calcification, } \\
\text { appropriate site for purse-strings, } \\
\text { good placement, confident, no } \\
\text { improvement required. }\end{array}$ \\
\hline $\begin{array}{l}\text { Checklist for initiation } \\
\text { - Checks ACT } \\
\text { - Ensure Good swing } \\
\text { - Team communication } \\
\end{array}$ & $\begin{array}{c}\text { Not able } \\
\text { to do }\end{array}$ & $\begin{array}{l}\text { Unsure and hesitant in taking steps } \\
\text { to initiate. Forgets to check swing / } \\
\text { ACT. Not clear in communication. }\end{array}$ & & $\begin{array}{c}\text { Partial checklist, or not clear in } \\
\text { commands - able to initiate CPB but } \\
\text { could be improved. }\end{array}$ & & $\begin{array}{l}\text { Good communication and complete } \\
\text { checklist. No improvement } \\
\text { required. }\end{array}$ \\
\hline $\begin{array}{l}\text { Commencement of bypass } \\
\text { - Check line pressure } \\
\text { /venous drainage } \\
\text { - Communicate / respond to } \\
\text { concerns }\end{array}$ & $\begin{array}{l}\text { Not able } \\
\text { to do }\end{array}$ & $\begin{array}{l}\text { Uncertain and hesitant in } \\
\text { responding to concerns. Does not } \\
\text { check or recognise issues with } \\
\text { drainage / pressure. }\end{array}$ & & $\begin{array}{l}\text { Reasonable communication and } \\
\text { management of CPB. Could be } \\
\text { improved. Partial checks or needs } \\
\text { assistance or reassurance in dealing } \\
\text { with complications. }\end{array}$ & & $\begin{array}{l}\text { Good management of CPB. Checks } \\
\text { line pressure and drainage, able to } \\
\text { communicate and respond to } \\
\text { concerns of the team. }\end{array}$ \\
\hline $\begin{array}{l}\text { Management during bypass } \\
\text { - Vent placement } \\
\text { - Cross clamp } \\
\text { - Delivery of cardioplegia } \\
\end{array}$ & $\begin{array}{l}\text { Not able } \\
\text { to do }\end{array}$ & $\begin{array}{l}\text { Frequently stopped, uncertain or } \\
\text { tentative approach. Technically } \\
\text { UNABLE to place vent or cross- } \\
\text { clamp safely and clearly. Poor } \\
\text { communication. }\end{array}$ & & $\begin{array}{l}\text { Reasonable efficiency, reasonable } \\
\text { skill in placement of vent and } \\
\text { clamp. Able to communicate with } \\
\text { the team safely but the process } \\
\text { could be improved. }\end{array}$ & & $\begin{array}{l}\text { Maximum efficiency and good skill } \\
\text { in placement of vent and clamp. } \\
\text { Good communication. No } \\
\text { improvement required. }\end{array}$ \\
\hline $\begin{array}{l}\text { De-airing and removal of cross } \\
\text { clamp } \\
\text { - Safe technique } \\
\text { - Asks for filling and } \\
\text { ventilation } \\
\text { - De-air technique } \\
\end{array}$ & $\begin{array}{l}\text { Not able } \\
\text { to do }\end{array}$ & $\begin{array}{l}\text { Awkward and unsure -needs } \\
\text { guidance or prompting. Unsafe } \\
\text { procedure to de-air or remove } \\
\text { clamp. Poor communication. }\end{array}$ & & $\begin{array}{l}\text { Reasonably safe actions and } \\
\text { efficiency in de-airing and removal } \\
\text { of clamp. Able to communicate but } \\
\text { the process could be improved. }\end{array}$ & & $\begin{array}{l}\text { Maximum efficiency-good skill in } \\
\text { de-airing and removal. No } \\
\text { improvement required. Good } \\
\text { communication throughout. }\end{array}$ \\
\hline $\begin{array}{l}\text { Preparation for termination } \\
\text { - Checklist* } \\
\text { - communication }\end{array}$ & $\begin{array}{c}\text { Not able } \\
\text { to do }\end{array}$ & $\begin{array}{c}\text { Awkward and hesitant. Poor } \\
\text { preparation - does not complete all } \\
\text { steps, requires prompting and help } \\
\text { from senior. Unsafe procedure. } \\
\text { Poor communication. }\end{array}$ & & $\begin{array}{c}\text { Adequate preparation and } \\
\text { procedure - needs some prompting } \\
\text { or reassurance. Reasonable } \\
\text { communication, completes steps } \\
\text { and is safe but aspects could be } \\
\text { improved. }\end{array}$ & & $\begin{array}{l}\text { Efficient and safe preparation. } \\
\text { Good communication. Completes all } \\
\text { steps safely. Does not require } \\
\text { improvement. }\end{array}$ \\
\hline Decannulation & $\begin{array}{c}\text { Not able } \\
\text { to do }\end{array}$ & $\begin{array}{l}\text { Awkward or hesitant. Poor } \\
\text { communication with assistant or } \\
\text { team. Unsafe procedure. }\end{array}$ & & $\begin{array}{c}\text { Reasonable procedure. Able to } \\
\text { safely decannulate and } \\
\text { communicate but could be } \\
\text { improved. }\end{array}$ & & $\begin{array}{l}\text { Safe and good decannulation with } \\
\text { good communication throughout. } \\
\text { Does not need improvement. }\end{array}$ \\
\hline Overall communication & & Poor & & Reasonable & & Excellent \\
\hline
\end{tabular}

${ }^{*}$ Checklist for termination preparation : ECG / Pacing / Blood pressure / Temp / Ventilation / Haemostasis/ Electrolyte

FIGURE 4. Objectively structured assessment of technical skills (OSATS) matrices adapted for pulmonary wedge resection (PWR) and cardiopulmonary bypass $(C P B)$, and recognized assessment sources demonstrated global ranking scale. ACT, Activated clotting time; ECG, electrocardiogram.

OSATS assessment was undertaken 1 week before and 2 weeks after each boot camp. It was not possible to assess all 20 trainees in both skills simultaneously, but where possible this was performed. The same supervisor was used to provide consistency over the year. Although the courses and assessments were compulsory components of annual training, the trainees were invited to voluntarily participate with implied consent.

Each procedure was categorized into subskills shown on the OSATS matrices presented in Figures 3 and 4.

\section{Method 2: Clinical Supervisor Survey}

An online questionnaire was designed to gather more information regarding effects on development (Figure 5). These were completed by a surgeon with direct observation of the resident in and out of operating rooms. The 4 domains questioned were knowledge, decision making, technical skills, and confidence. These 4 facets are routinely assessed by faculty in weekly progression assessments throughout resident training. As such, detailed descriptors were not necessary.

The confidence of the supervising surgeon to allow participation in clinical activity after each course was explored. Feeling confident to allow a resident more autonomy in work reflects an applied understanding of their ability that we sought to measure.

\section{Statistical Analysis}

All analyses were performed using SPSS version 22 statistical analysis software (IBM-SPSS Inc, Armonk, NY). Pre- and postcourse OSATS scores for overall performance and subskills were nonnormally distributed and so were analyzed using Wilcoxon signed-rank tests and the sequential Bonferroni technique. The difference in pre- and postcourse OSATS scores was used as the primary outcome measure. Survey scores were summarized using standard descriptive statistics and converted to diverging stacked charts for clarity of interpretation.

\section{RESULTS \\ Data Completeness}

Boot camp 1 consisted of 20 candidates who returned 23 assessments overall (CPB, $\mathrm{n}=15$ and PWR, $\mathrm{n}=8)$. One hundred percent of candidates returned complete assessments and $100 \%$ of clinical supervisors completed survey questions following boot camp 1.

Boot camp 2 consisted of 20 candidates who returned 16 assessments overall (CPB, $\mathrm{n}=8$ and PWR, $\mathrm{n}=8$ ). Two candidates at boot camp 2 were excluded due to absent counterpart (a precourse form was available but no postcourse form). A further 2 candidates did not return any assessments. Following exclusion, $80 \%$ of assessments were analyzed $(n=16)$. Seventy-five percent of clinical supervisors completed survey questions following boot camp 2 .

\section{Method 1: Objective Skills Assessment}

Both boot camps were found to produce significant improvement overall in objective assessment of trainee performance in CPB and PWR.

Candidate total score pre- and postcourse was analyzed using a 2-tailed Wilcoxon signed-rank test. Maximum 


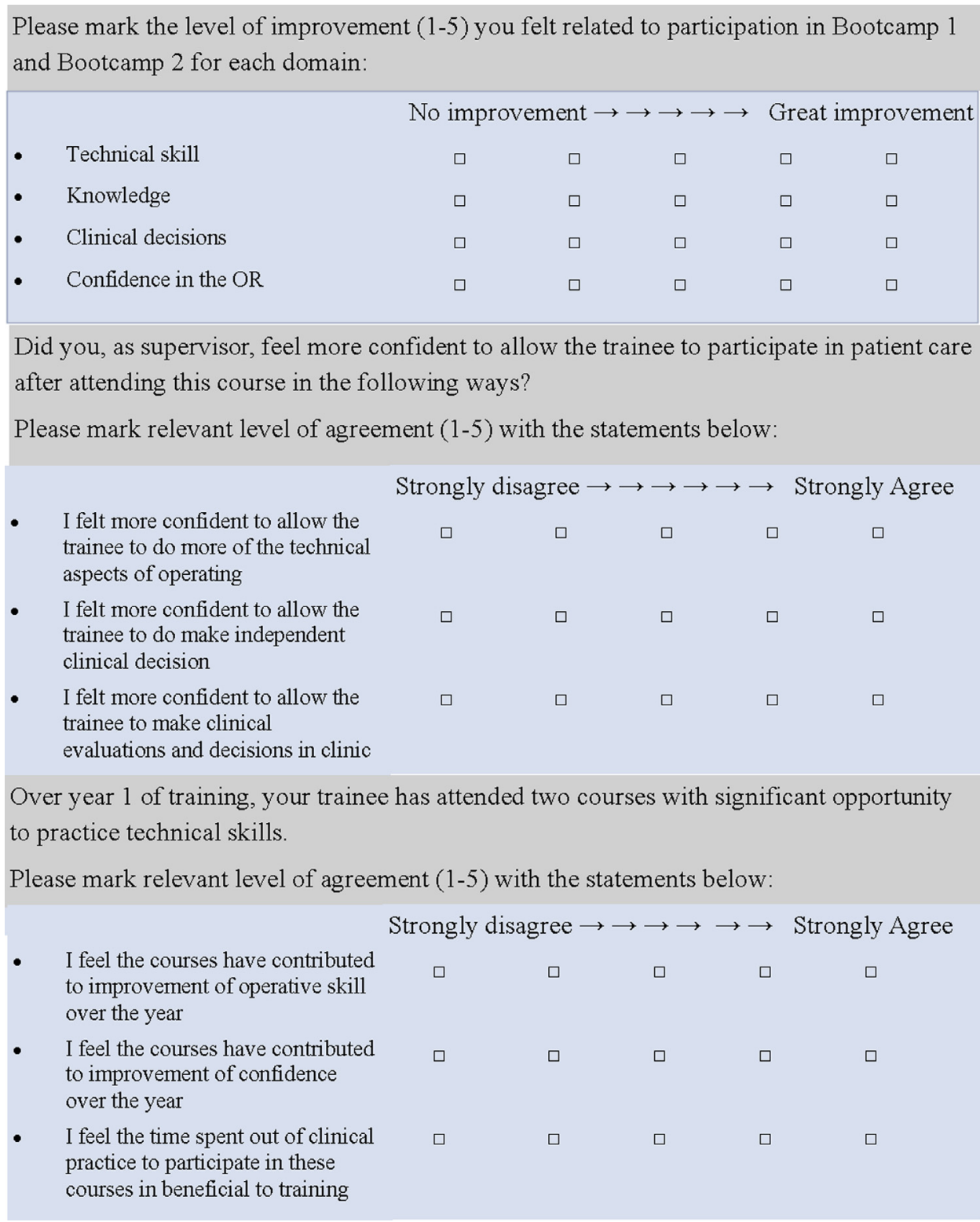

FIGURE 5. Online survey completed by clinical supervisors.

potential score was 40 if a candidate scored 5 in all 8 domains. In boot camp $1(\mathrm{n}=8)$, median total score was 25.0 (quartile 1-quartile 3, 23-28.25) precourse and 32.0 (quartile 1-quartile 3, 29.75-35.5) postcourse. In boot camp $2(\mathrm{n}=8)$ these values were 31.5 (quartile 1-quartile $3,25.5-34$ ) precourse and 37.0 (quartile 1-quartile 3, 35.75-39.25) postcourse. This is a significant improvement in trainee performance of PWR after both courses $(P=.012$ and $P=.018$, respectively) (Figure 6).

The maximum potential total score was 35 if a candidate scored 5 in all 7 domains for CPB. In boot camp $1(\mathrm{n}=15)$, median total score was 21.0 (quartile 1-quartile 3, 18-23) precourse and 28.0 (quartile 1-quartile 3, 24.5-31.5) postcourse. In boot camp $2(\mathrm{n}=8)$, these values were 28.0 (quartile 1-quartile 3, 23.25-29) precourse and 30.5 (quartile 1-quartile 3,27.25-35) postcourse. This also represents a significant improvement in CPB management after both boot camp 1 and boot camp $2(P=.001$ and $P=.018$, respectively) (Figure 6).

Statistical analysis shows that during both boot camps, trainee performance of most PWR subskills improved (see Table 1). In both courses, trainees showed significant improvement in terms of port placement, use of a thoracoscope, tissue handling, and lung orientation. In some 

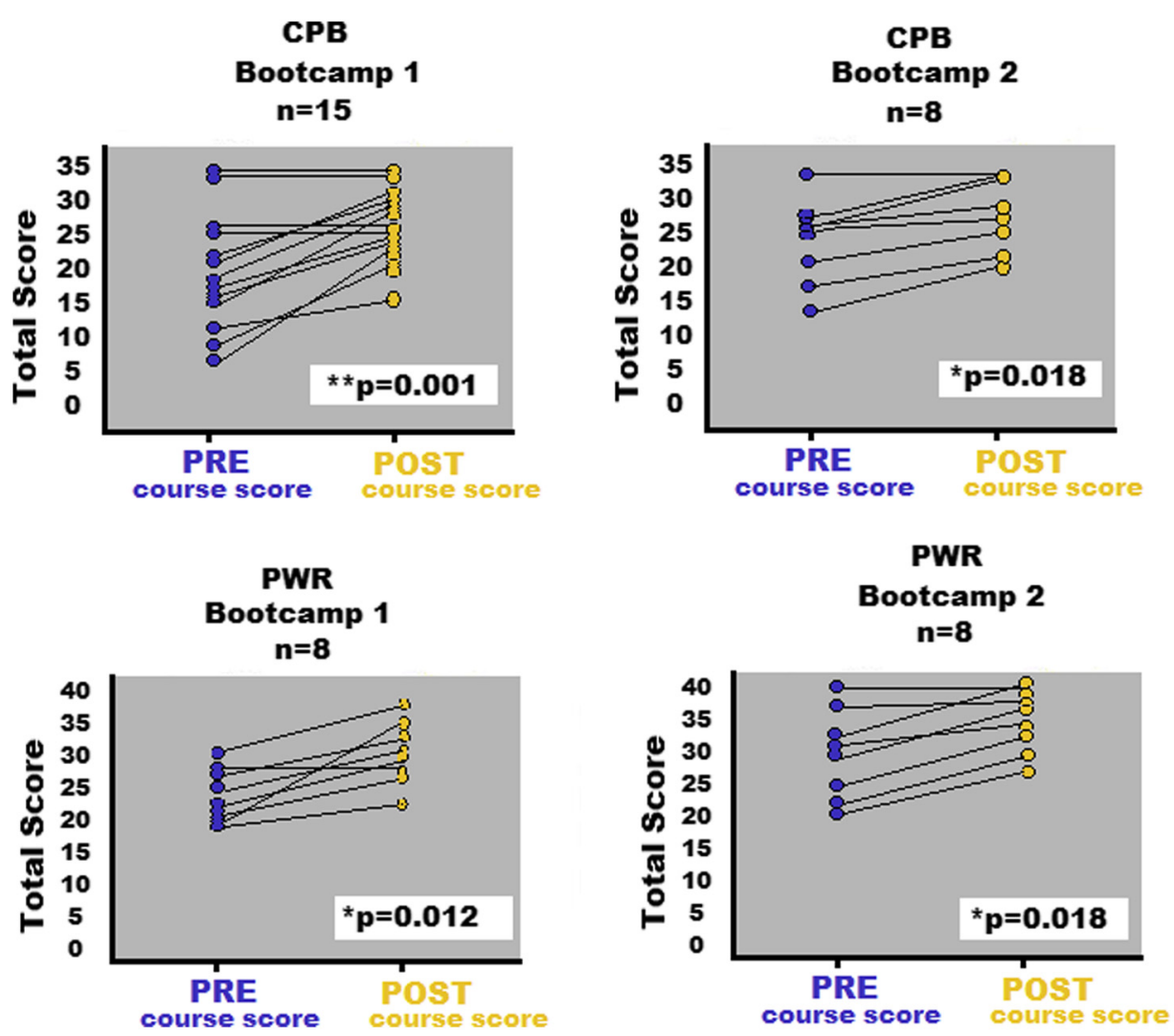

FIGURE 6. Total score pre- and postcourse for pulmonary wedge resection $(P W R)$ and cardiopulmonary bypass $(C P B)$. Each line represents an individual trainee.

subskills domains, including stapling, pneumostasis, extraction, and closure, we could not consistently establish an improvement in performance.

During boot camp 1 improvement in all CPB subskill domains was noted. However, following boot camp 2, we found only significant improvement in the preparation and checklist domains.

\section{Method 2: Supervisor Survey}

Clinical supervisor ranking scales of trainees' improvement in knowledge, decision making, technical skills, and confidence are clearly shown in Figure 7. Two supervisors were unable to comment and have been excluded from data analysis. It can be seen that the majority of opinion is positive.

Figure 8 shows Likert outcomes related to supervisor confidence, an indirect measurement of boot camp influence. No supervisors strongly disagreed with any of the 3 category statements.

Subsequent questions related to the supervisors' support for the course (see Figure 9). It was found that $83.3 \%$ of trainers agreed or strongly agreed that time spent out of clinical practice is beneficial. It was also found that $83.3 \%$ of trainers agreed or strongly agreed they would support trainees in attending boot camp 1 in future years, with $16.6 \%$ having no strong opinion either way. It was found that $83.3 \%$ of trainers agreed or strongly agreed they would support candidates in attending boot camp 2. It was found that $8.4 \%(n=1)$ strongly disagreed with supporting a subsequent trainee in attending the course. No free text was added to explain this opinion.

\section{DISCUSSION}

Across surgical specialties, there has been a surge of simulation and intensive boot camp-style courses to bridge the gap and complement training in vivo. Cleland and colleagues ${ }^{20}$ wrote recently that surgery boot camps are not just a hive of increased surgical acumen, but also that these events are as much about social and cultural processes. Boot camp-style courses should be used and perceived not only as a bridge, but also as a valuable tool in the multifaceted training armamentarium. ${ }^{14,16,21-23}$

We believe that the significant improvement in technical skills and confidence following our boot camp arose from targeting the salient curricula components for the stage of surgeon to structure a course that aligns comfortably with in-work training. Furthermore, utilizing this structure to establish the deliberate components of sustained deliberate 
TABLE 1. Mean trainee scores in subskills and values for Wilcoxon signed-rank test for pulmonary wedge resection and cardiopulmonary bypass

\begin{tabular}{|c|c|c|c|c|c|c|c|c|}
\hline \multirow[b]{3}{*}{ Subskill } & \multicolumn{4}{|c|}{ Boot camp 1} & \multicolumn{4}{|c|}{ Boot camp 2} \\
\hline & \multicolumn{2}{|c|}{ Mean score } & \multirow[b]{2}{*}{$Z$ value } & \multirow[b]{2}{*}{$P$ value } & \multicolumn{2}{|c|}{ Mean score } & \multirow[b]{2}{*}{$Z$ value } & \multirow[b]{2}{*}{$P$ valu } \\
\hline & Pre-course & Post-course & & & $\overline{\text { Pre-course }}$ & Post-course & & \\
\hline Pulmonary wedge resection & \multicolumn{4}{|c|}{$\mathrm{n}=8$} & \multicolumn{4}{|c|}{$\mathrm{n}=8$} \\
\hline Access & 3.5 & 4.4 & -2.070 & $.038^{*}$ & 4.0 & 4.8 & -2.449 & $.014^{*}$ \\
\hline Thoracoscope & 3.5 & 4.6 & -2.251 & $.024 *$ & 4.0 & 4.8 & -2.121 & $.034 *$ \\
\hline Tissue handling & 3.0 & 4.0 & -2.271 & $.023^{*}$ & 3.9 & 4.5 & -2.236 & $.025^{*}$ \\
\hline Orientation & 2.5 & 3.5 & -2.060 & $.039^{*}$ & 3.6 & 4.4 & -2.449 & $.014^{*}$ \\
\hline Stapling & 3.5 & 4.1 & -1.890 & $.059^{*}$ & 3.8 & 4.8 & -2.333 & $.020^{*}$ \\
\hline Pneumostasis & 2.6 & 3.1 & -1.633 & $.102 *$ & 3.8 & 4.8 & -2.333 & $.020^{*}$ \\
\hline Extraction & 3.3 & 4.1 & -2.070 & $.038^{*}$ & 3.9 & 4.5 & -1.667 & .096 \\
\hline Closure & 4.0 & 4.6 & -1.667 & .096 & 3.9 & 4.6 & -1.730 & .084 \\
\hline Cardiopulmonary bypass & \multicolumn{4}{|c|}{$\mathrm{n}=15$} & \multicolumn{4}{|c|}{$\mathrm{n}=8$} \\
\hline Preparation & 3.1 & 4.1 & -3.217 & $.001 \dagger, \ddagger$ & 4.0 & 4.7 & -2.121 & $.043^{*}$ \\
\hline Checklist & 3.3 & 4.3 & -2.889 & $.004+, \ddagger$ & 3.9 & 4.5 & -2.236 & $.025^{*}$ \\
\hline Commencement & 3.1 & 4.2 & -2.722 & $.006+$, & 3.5 & 4.3 & -1.857 & .063 \\
\hline $\begin{array}{l}\text { Management during } \\
\text { cardiopulmonary bypass }\end{array}$ & 2.7 & 3.3 & -2.456 & $.014^{*}$ & 3.1 & 4.0 & -1.841 & .066 \\
\hline De-airing & 2.3 & 3.3 & -2.719 & $.007 \dagger, \ddagger$ & 3.1 & 3.9 & -1.890 & .059 \\
\hline Preparation for termination & 2.7 & 3.9 & -3.022 & $.003+, \ddagger$ & 3.4 & 3.9 & -1.134 & .257 \\
\hline Decannulation & 2.7 & 3.8 & -3.022 & $.003+, \ddagger$ & 3.6 & 4.0 & -1.342 & .180 \\
\hline
\end{tabular}

$* P<.05 . \dagger P<.01$. \\ignificant at $P=.05$ level after application of the sequential Bonferroni technique. ${ }^{10}$

practice, which requires focus, allows engagement of residents in sustained deliberate practice and the opportunity to err without consequence.

It should be noted that this study compared only the technical training and did not examine the clinical skills of history taking, physical examination, imaging interpretation, or clinical decision making, all of which are fundamental attributes of a holistic surgeon. Although this course may be invaluable in the improvement of technical skills and confidence, we consider it another asset in the training toolbox, excelling alongside in-work education, particularly where targets and objectives align.

The United Kingdom is a small country, with as few as 20 training surgeons a year and a similar number of faculty surgeons available to assess. As such, studies of each cohort are limited by the very nature of the specialization of cardiothoracic surgery. Engagement of trainees and supervisors in an already paperwork-overloaded career is a challenge. We chose not to incentivize and as such, despite multiple means of communication and requests, data completeness did not

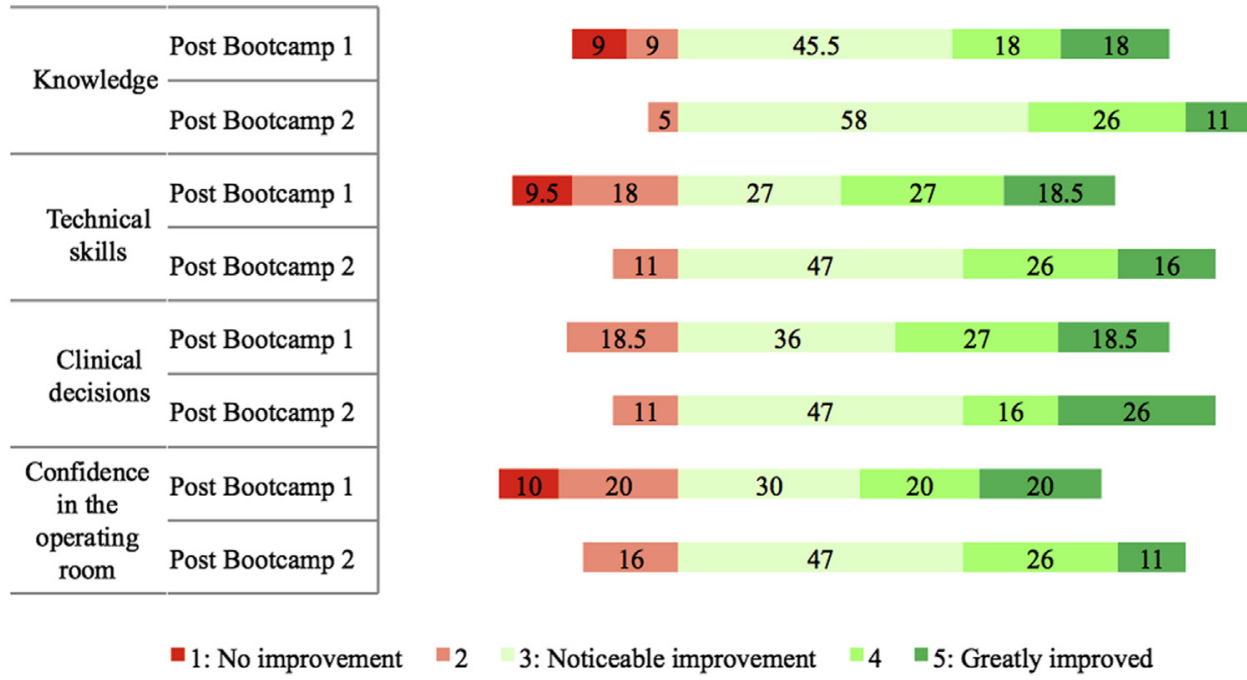

FIGURE 7. Clinical supervisor opinions per Likert scales plotted onto a diverging stacked chart to demonstrate influence of boot camp courses on learning domains (percentages shown of each ranking outcome in the whole group [boot camp 1, $\mathrm{n}=19$ and boot camp 2, $\mathrm{n}=13$ ]). 


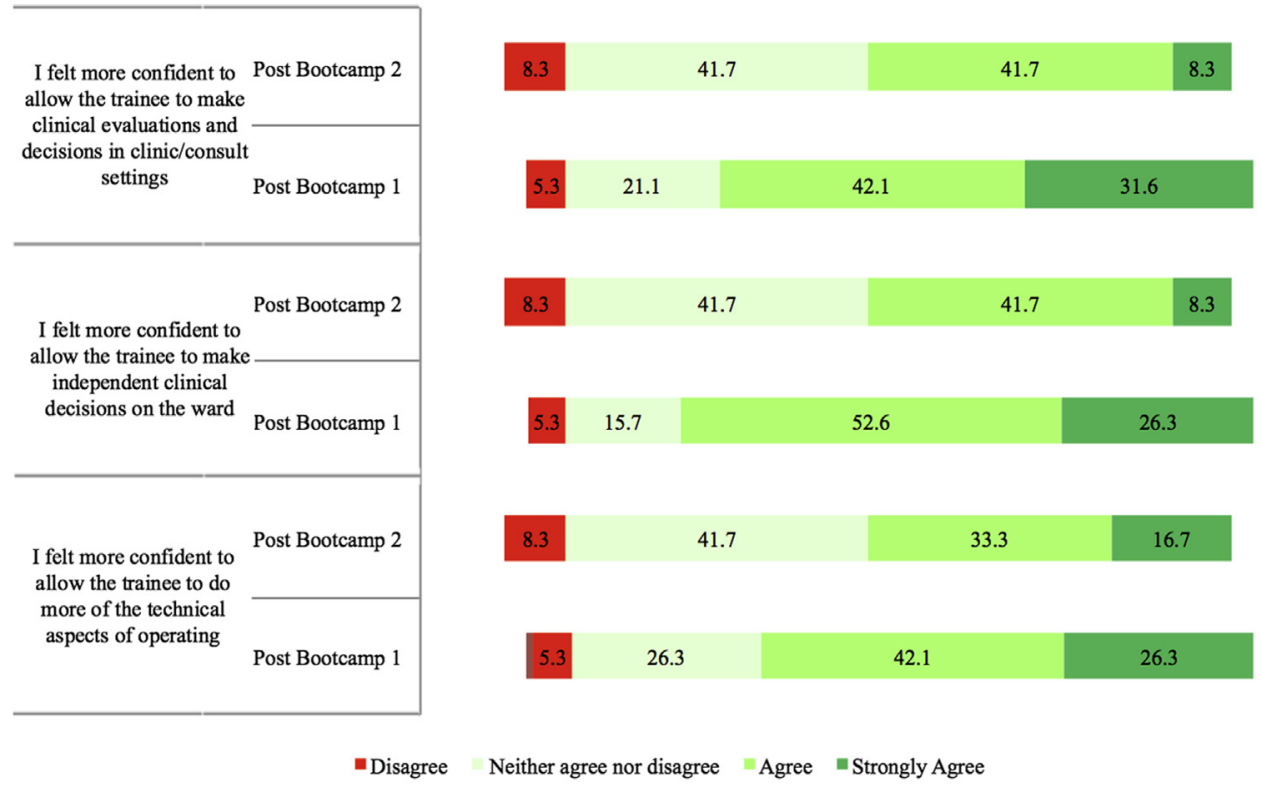

FIGURE 8. Clinical supervisor ranking scales to demonstrate trainer confidence in candidate in different clinical settings (percentages of the whole group [boot camp 1, $\mathrm{n}=19$ and boot camp 2, $\mathrm{n}=15]$ ).

reach $100 \%$ from both trainees and trainers. We hope that with this demonstration of positive outcomes, future engagement will be superior.

Surgeons, residents, and patients alike have a right to question if training outside of the workplace should be implemented to not only improve confidence and performance, but also to document competency. ${ }^{24-27}$ In developing our preliminary OSATS through integration and blueprinting of validated performance scales, we have established a robust building block for a comprehensive assessment tool that continues to evolve.

This study is not the first to evaluate improvement in technical skills as a direct result of LAO or simulation.
What is unique is showing that 2 weeks after training, skills were not only retained, but also taken back to the real-world environment and applied to patient care. Boot camp alone, without subsequent, imminent exposure to the technical skill, has been shown to have little effect on long-term retention. ${ }^{8,28}$ As such, residents are encouraged to discuss the boot camp experience with their trainers, clearly outline the skills practiced, and set objectives to harness the immediate opportunity for further development.

Four trainees did not show significant improvement in overall assessment; however, these tended to be the candidates already scoring 4 or 5 precourse. In the United Kingdom, first-year residents may have experience in
I feel the courses have contributed to the improvement of my trainees' operative skill over the year

I would support trainees in subsequent years attending Bootcamp 2

I would support trainees in subsequent years attending Bootcamp 1

I feel the time spent out of clinical practice to participate in these courses is beneficial to training

I feel the courses have contributed to the improvement of trainees' confidence over the year

\begin{tabular}{|l|l|}
25 & 58.3 \\
\hline
\end{tabular}

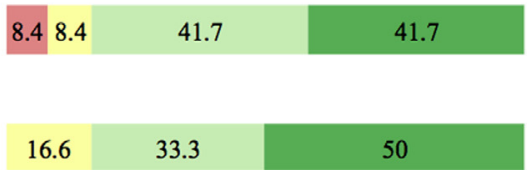

\begin{tabular}{|l|r|r|}
16.6 & 33.3 & 50
\end{tabular}

16.6
58.3

- Disagree Neither agree nor disagree $\quad$ Agree $\quad$ Strongly agree

FIGURE 9. Likert scale representation of clinical supervisors' general opinion of the influence of the courses (percentages of the whole group [N $=15]$ ). 


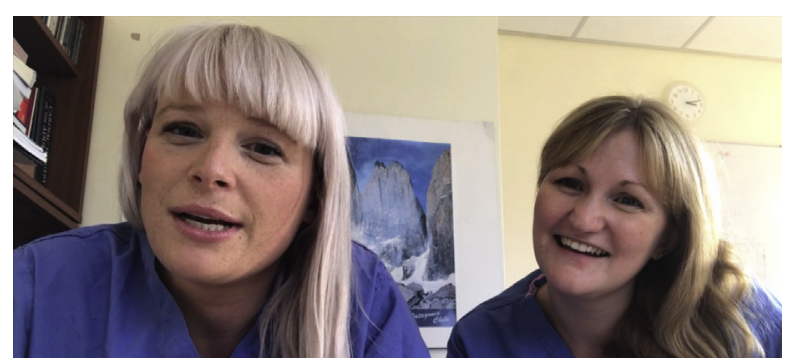

VIDEO 1. Louise Kenny is interviewed regarding background to the boot camp, the courses and involvement of live animal operating, and the study structure. Video available at: http://www.jtcvsonline.org/article/S00225223(18)30373-8/fulltext.

cardiothoracic surgery for a number of years before appointment and have already achieved competency unaffected by skills training on a simulator. Surgeons train at different speeds with different stimuli, and as such it is not expected that all will improve following boot camp.

Caution must be exercised when comparing the statistical analyses and $P$ values of the 2 courses described here. Although a smaller $P$ value was calculated during analysis of the boot camp 1 course, this does not necessarily mean the course caused greater improvement in performance than did boot camp 2. It is possibly a reflection of the larger samples size $(\mathrm{n}=15$ and $\mathrm{n}=8$, respectively) (see Appendix E1 for power calculations).

Similarly, in the analysis of subskills not all categories demonstrated improvement. This could be due to a difference in the utility of the materials; for example, the manner in which LAO lends itself to tissue-handling training or the presence of a living lung and true ventilation forcing diligent development of pneumostasis skills. But we suspect it is more likely a reflection of the small sample sizes.

The opportunity to operate on live tissue with beating a heart means trial and error can be employed to determine realistic effects on tissue-handling techniques. Needle angles, tips, and tricks can be trialed with essentially reproducible outcomes to human tissue, without risk to a human patient, and no impending threat of the trainer taking over.

It does carry limitations and ethical consideration. Yoo and colleagues ${ }^{29}$ describe LAO as "expensive, laborious and hardly applicable." Its use is limited in the United Kingdom by animal welfare legislation and we are fortunate to permit each trainee 3 visits to Europe to undertake LAO during the 6-year training program with committed funding. We have had no resident object to LAO, but we wonder if the strong disagreement with future attendance at boot camp 2 by 1 supervisor could be related to ethics surrounding live animals. Given the lack of free-text responses, this is simply a hunch based on the positive responses of this supervisor to all aspects apart from LAO-related questions. Seventeen percent of supervisors neither agreed nor disagreed with supporting further attendance at boot camp 1, without free-text clarification. Our supposition is that there is still a firm grasp on the apprentice model of training, although attitudes are shifting to allow time off work to attend courses.

Yoo and colleagues ${ }^{29}$ recently demonstrated the power of printed models for the accuracy of complex pathology on the cardiac spectrum. However, the weakness of these models is primarily related to the difference from human tissue in relation to tensile strength and consistency. Conversely in LAO, pathology cannot be guaranteed, but evaluating, repairing, and reviewing on living perfused tissue is invaluable. The future perhaps holds a combination of printed pathology with living tissue.

\section{Limitations}

Our study is based on a single-subject design, with participants acting as their own controls providing sensitivity to individual differences. This meant we were able to offer the educational opportunity to all, rather than omit a control group. Ideally, multiple baseline and intervention scores would be analyzed for each candidate to reduce bias; however, in-theatre assessment must be an acceptable workload for clinical supervisors.

Methodologic problems with OSATS include the reliance on observers' interpretation of wording of key behaviors such as "consistently handles tissue with care" or, "tentative and awkward approach to cannulation." Although there is no implicit definition between surgeons of such text, all assessors in this study are trained clinical supervisors and faculty surgeons who are familiar with this type of assessment and wording. ${ }^{30}$ The use of a single unblinded assessor may introduce bias. However, we believe assessment in an actual operating room was the maximally important outcome, and use of multiple assessors or film posed logistical and ethical implications that were too great for this introductory study. Moreover, it is standard practice in the United Kingdom for a solitary trainer to do repeated and consistent assessments on a trainee to map progress. ${ }^{18}$

We recognize that no validity study for this OSATS matrix exists, but adaptations are taken from previously published and established performance measures to provide a functional assessment tool. ${ }^{6,21,30}$ With consequent groups we aim to validate the assessment process and provide interobserver reliability, reducing bias and increasing construct validity.

\section{CONCLUSIONS}

Surgeon training is challenging in the current climate. Intensive competency-targeted simulation courses integrated into workplace programs can significantly improve technical skills in first-year resident physicians. Trainers are confident to allow greater participation in clinical practice following these courses and positively support attendance for future cardiothoracic surgeons in training. An interview between lead author, and resident trainee $\mathrm{Dr}$ Louise Kenny, and author and training supervisor Dr Karen 
Booth, reflecting upon UK training, boot-camp, and the research project is available in Video 1.

\section{Webcast}

You can watch a Webcast of this AATS meeting presentation by going to: https://aats.blob.core.windows.net/ media/17AM/2017-05-03/RM302-304/05-03-17_Room302304_0806_Kenny.mp4.

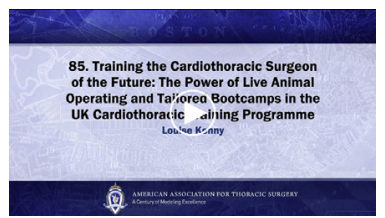

\section{Conflict of Interest Statement}

Ethicon Inc (Somerville, NJ) provided financial support for the equipment, venue, travel, and accommodation of the trainees and faculty. Authors have nothing to disclose with regard to commercial support.

The authors thank our surgeon colleagues: $\operatorname{Mr}(\mathrm{s})$ Cooper, Lewis, Shah, Page, Dunning, and Barnard; Drs Pearce, Gray, and Hanson; and the staff at the European Surgical Institute.

\section{References}

1. Moorjani N, Lewis M, Shah R, Barnard S, Graham T, Rathinam S. Implementation of a novel portfolio of structured, curriculum-aligned, simulation-based, cardiothoracic surgery training courses: evolving the delivery of surgical education. J Thorac Cardiovasc Surg. 2017:154:2009-16.

2. Stoica SC, Kalavrouziotis D, Martin BJ, Buth KJ, Hirsch GM, Sullivan JA, et al. Long-term results of heart operations performed by surgeons-in-training. Circulation. 2008;118:S1-6.

3. DeLaRosa J, Thourani VH, Wheatley GH III, McMullan DM, Karamanoukian RL, Greene MG, et al. Impact of resident duty hour standards on cardiothoracic residents and program directors. Ann Thorac Surg. 2005;80:1569-71.

4. Lim E, Tsui S. Impact of the European working time directive on exposure to operative cardiac surgical training. Eur J Cardiothorac Surg. 2006;30:574-7.

5. Anders Ericsson KK, Tesch-Roemer C. The role of deliberate practice in the acquisition of expert performance. Psychol Rev. 1993;100:363-406.

6. Hicks GL Jr, Gangemi J, Angona RE Jr, Ramphal PS, Feins RH, Fann JI. Cardiopulmonary bypass simulation at the Boot Camp. J Thorac Cardiovasc Surg. 2011;141:284-92.

7. Trehan K, Kemp CD, Yang SC. Simulation in cardiothoracic surgical training: where do we stand? J Thorac Cardiovasc Surg. 2014;147:18-24.e2.

8. Ceresnak SR, Axelrod DM, Motonaga KS, Johnson ER, Krawczeski CD. Pediatric cardiology boot camp: description and evaluation of a novel intensive training program for pediatric cardiology trainees. Pediatr Cardiol. 2016;37:834-44.

9. Sturm L, et al. Surgical Simulation for Training: Skills Transfer to the Operating Room. ASERNIP-S Report No. 61. Adelaide, Australia: ASERNIP-S; July 2007.

10. Wagh MS, Waxman I. Animal models for endoscopic simulation. Gastrointest Endosc Clin North Am. 2006;16:451-6.

11. Chapman DM, Rhee KJ, Marx JA, Honigman B, Panacek EA, Martinez D, et al. Open thoracotomy procedural competency: validity study of teaching and assessment modalities. Ann Emerg Med. 1996;28:641-7.

12. Kneebone R. Simulation, safety and surgery. Qual Saf Health Care. 2010; 19(Suppl 3):i47-52.

13. Physicians Committee for Responsible Medicine. Physicians Committee praises Johns Hopkins University's decision to end animal use in medical education. Available at: http://www.pcrm.org/media/news/johns-hopkins-university-endsanimal-use-in-medical-education. Accessed May 18, 2016.
14. Fann JI, Calhoon JH, Carpenter AJ, Merrill WH, Brown JW, Poston RS, et al Simulation in coronary artery anastomosis early in cardiothoracic surgical residency training: the boot camp experience. J Thorac Cardiovasc Surg. 2010; 139:1275-81.

15. Hance J, Aggarwal R, Stanbridge R, Blauth C, Munz Y, Darzi A, et al. Objective assessment of technical skills in cardiac surgery. Eur J Cardiothorac Surg. 2005; 28:157-62.

16. Reznick RK, MacRae H. Teaching surgical skills—changes in the wind. N Engl J Med. 2006;355:2664-9.

17. Wessex Deanery national recruitment panel criteria 2010. Available at: http:// www.wessexdeanery.nhs.uk/recruitment/national_ct_surgery_st1_st3/st3_interview_ score_criteria.aspx. Accessed December 12, 2017.

18. Intercollegiate Surgical Curriculum Programme Assessment overview. Available at: https://http://www.iscp.ac.uk/surgical/assessment_overview.aspx. Accessed December 7, 2017.

19. Rice WR. Analyzing tables of statistical tests. Evolution. 1989;43:223-5.

20. Cleland J, Walker KG, Gale M, Nicol LG. Simulation-based education: understanding the socio-cultural complexity of a surgical training 'boot camp'. Med Educ. 2016;50:829-41.

21. Beard JD, Jolly BC, Newble DI, Thomas WE, Donnelly J, Southgate LJ. Assessing the technical skills of surgical trainees. Br J Surg. 2005;92:778-82.

22. Carpenter AJ, Yang SC, Uhlig PN, Colson YL. Envisioning simulation in the future of thoracic surgical education. J Thorac Cardiovasc Surg. 2008;135: 477-84.

23. Reznick R, Regehr G, MacRae H, Martin J, McCulloch W. Testing technical skill via an innovative "bench station" examination. Am J Surg. 1997; 173:226-30

24. Asimakopoulos G, Karagounis AP, Valencia O, Rose D, Niranjan G, Chandrasekaran V. How safe is it to train residents to perform off-pump coronary artery bypass surgery? Ann Thorac Surg. 2006;81:568-72.

25. Baskett RJ, Kalavrouziotis D, Buth KJ, Hirsch GM, Sullivan JA. Training residents in mitral valve surgery. Ann Thorac Surg. 2004;78:1236-40.

26. Caputo M, Reeves BC, Rogers CA, Ascione R, Angelini GD. Monitoring the performance of residents during training in off-pump coronary surgery. $J$ Thorac Cardiovasc Surg. 2004;128:907-15

27. Haan CK, Milford-Beland S, O'Brien S, Mark D, Dullum M, Ferguson TB, et al Impact of residency status on perfusion times and outcomes for coronary artery bypass graft surgery. Ann Thorac Surg. 2007;83:2103-10.

28. Anastakis DJ, Wanzel KR, Brown MH, McIlroy JH, Hamstra SJ, Ali J, et al. Evaluating the effectiveness of a 2-year curriculum in a surgical skills center. Am J Surg. 2003;185:378-85.

29. Yoo SJ, Spray T, Austin EH III, Yun TJ, van Arsdell GS. Hands-on surgical training of congenital heart surgery using 3-dimensional print models. J Thorac Cardiovasc Surg. 2017;153:1530-40.

30. Martin JA, Regehr G, Reznick R, MacRae H, Murnaghan J, Hutchison C, et al Objective structured assessment of technical skill (OSATS) for surgical residents Br J Surg. 1997;84:273-8.

Key Words: surgical simulation, cardiothoracic training, boot-camp, skill transfer

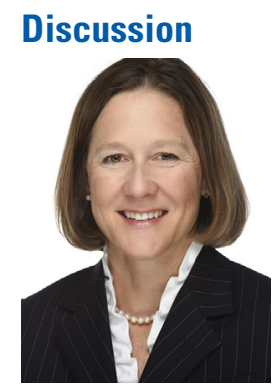

Dr Jennifer Lawton (Baltimore, $M D$ ). Congratulations on an excellent presentation and also on your efforts to move this field forward. I have 3 questions for you.

The courses you provided, the 3-day simulation and the 3-day hands-on clinic using wedge and cardiopulmonary bypass had only complete surveys on 15 trainees for the first and 8 for the second, and, as you stated, data 
were obtained before and after the sessions. Other people have performed similar boot camps, typically ranging between 2 and 5 days. They also have demonstrated improved confidence, not only on the level of the trainees, which you did not assess, but also skill benefits. However, these skill benefits tended to diminish over time during training.

So my first question is: Do you have any data to suggest that the improvements you observed would be sustained over time, or does this really require continuous learning, as we heard from Dr Sundt in his address?

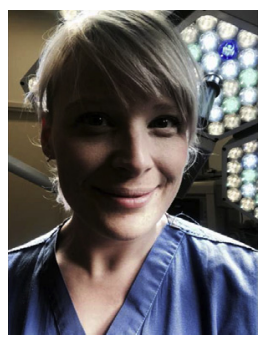

Dr Louise Kenny (Newcastle Upon Tyne, United Kingdom). I think it is difficult to establish sustained training because we don't know where they learned what, and so it is hard to look at them over time to see whether they have maintained their skills. I don't have any data. I do have some qualitative information from trainees, and it refers particularly to the confidence point. They go back to work the next week and they say, "I did this last week. Can I do it today?" And suddenly they start doing something that wasn't in their repertoire perhaps 2 weeks ago and then suddenly that becomes something that is in their repertoire. So they are continuing to learn because of the influence of the course. So I don't know if they sustain that actual technical skill, but I think it does help to develop them further, yes.

Dr Lawton. And another thing is I think the way the new generation has learned is very different than the way I learned a while back.

In your study, confidence level was assessed by the trainers not the trainees. Why do you think only $83 \%$ of trainers would support attendance in a future course? And actually it looked like you had 1 trainer who strongly disagreed with future courses despite the fact that they were completely paid for. Why do you think they did not uniformly support this?

Dr Kenny. The 1 trainer who strongly disagreed with further attendance was interesting, because that trainee did well. It wasn't that there was a negative influence on the trainee; the pre- and postcourse assessment showed improvement. But the assessor - the supervisor - did not want future trainees to attend, and that was specifically directed at the live animal operating course. There was a free-text box, but unfortunately there was no answer that explained why he felt so strongly against it, and I wonder if I it maybe was to do with the live animals rather than the training that takes place in the course.

I think there is also a group of surgeons who are still slightly resistant to this type of training, who think that we should just come to work, and perhaps they are right, we should just come to work and learn, but the opportunities aren't the same anymore. And so there is a small group that wonders what are we doing with this training course. So I think that's probably where that lack of support comes from.
Dr Lawton. My last question is somewhat rhetorical, but perhaps you can comment. You mentioned a lot of these things that we are all familiar with, the 10,000-hour rule for learning, and you mentioned some of the combined stresses that we have now. One is less time for teaching and we have to do more cases because a lot of centers are based on relative value units, public reporting, intense scrutiny of our outcomes, rapid evolution of technology, less open surgery, increased patient risk profiles, and the constraints of the workweek, which some have demonstrated could take 4800 hours off of training, result in increased intervals between case exposures with people being postcall, having to leave the hospital, and simulation sessions that may be somewhat short-lived in their benefits.

So in the future, how will we train our trainees to perform surgery in a safe way?

Dr Kenny. Yes, I think it is difficult. I don't think there is anything that will replace operating. I think we have to be in theatre and we have to be operating. But I think simulation, especially when it is integrated and there is a continued program of learning, can really complement that. I don't think there is any 1 simulator that is going to do the trick. There are problems with people who find the ethics difficult-the animals don't have pathology but they are great for training in this way. The printed models are excellent for pathology, but we all agree they are not great for stitching and for practicing. So I think it will be a combination of all this multifaceted training that we can put on top of in-theatre training and training in operating rooms that will lead to surgeons being better trained.

I also think there is a role at the moment, particularly in the United Kingdom, I don't know about America, but I think there is a matching problem. We have all seen trainees who have been put with the right surgeon at the right time and they have flown through, and similarly we have seen trainees who get stagnant with someone who perhaps doesn't train in a style that the trainee can respond to, and all of a sudden he or she has lost confidence and competence and finds him- or herself on the back foot. And so I think there is definitely a role for looking more into in the UK national matching for different types of trainers and trainees.

Dr Lawton. Perhaps you could give a postsession survey to those faculty and see what the barriers were with that 1 person; why he or she didn't want to do it again.

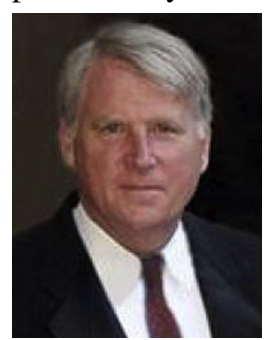

Dr J. Scott Rankin (Morgantown, WVa). I would like to compliment you on a great presentation and I totally agree with your thesis. Of course, this goes back to Blalock's program with the Hunterian Lab and all of the great surgeons Blalock trained who cut their teeth with Vivien Thomas in the Hunterian Lab at Hopkins, Bahnson, Cooley, and so on. 
In my training after the first 2 years of basic residency, Dr Sabiston made us do 2 years of research in the lab, and after that 2 years of operating. We'd come out much more confident in our own technical ability and hit the wards again with confidence doing our own operations. I think that this sort of thing is extremely important for the training of a surgeon. So congratulations. You did a great job.

Dr Kenny. Thank you.

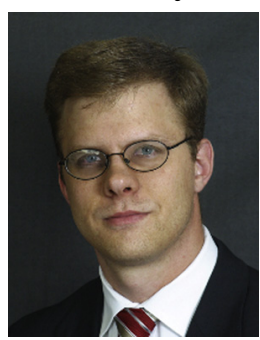

Dr Paul H. Schipper (Portland, Ore). We have a simulation program, including 1 live animal model. For the animal model, we do hilar dissection and wedge resections. As the residents finish what they are supposed to do for the curriculum, I have a couple of things I have them do until the time is up. One of them is take an 11 blade and put holes in the descending aorta and have them thoracoscopically repair the hole and/or convert to open. They keep making and repairing holes until the animal either dies or we run out of time.

Do you have any of this sort of thing that would fill a 10-, 15-, or 20-minute block at the end of the module?

Dr Kenny. Do you use bypass?

Dr Schipper. We do not have actual bypass for simulation. So this is like most general thoracic surgery, without bypass.

Dr Kenny. I am not a thoracic trainee, maybe Mr Moorjani would know, but I know that among the most helpful things for junior trainees is actually if you do something like pull the arterial pipe out and let them deal with it, and it is great to have done it on a pig. Hopefully, none of us ever see it, but to know that you can respond to that stress is a good way to train.

The other thing is we sort of could do grafts, and then once the pig does die we can flip the aorta inside out and see what the stitching is like and that sort of thing. So that is really helpful to see, too.

So thoracic, I'm not sure. Mr Moorjani?

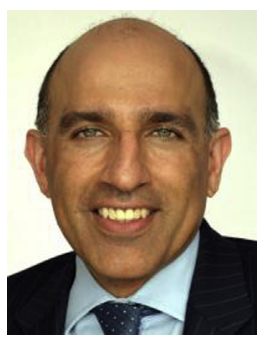

Dr Narain Moorjani (Cambridge, United Kingdom). This is more of a comment. To answer your last question, we run 3 courses using the live operating model, and the last 1 is to teach trainees who are about to become attendings. We run through the whole set of emergency situations, whether it is a hole in the right ventricle, a hole in the inferior vena cava when the cannula is put in, or displacement of cannulas coming on cardiopulmonary bypass. We run the whole spectrum from the cardiac point of view of emergencies and the same from the thoracic point of view. That is part of what we run in a 12-course program.

To answer the question earlier about the faculty member who was a little bit resistant, it is about educating the assessors about what the simulation courses are able to offer. A lot of people are reticent because they think of the old days where simulation had low fidelity. The live animal operating model that we have produces fantastic fidelity for training, as close to what is attainable in the operating room. And so I think it is a matter of educating faculty who are a little bit resistant. 


\section{APPENDIX E1}

Participants were recruited from available resources as opposed to using a power calculation. The power of the analysis was retrospectively calculated to aid interpretation. Table E1 demonstrates the differences in power in the analysis of boot camp 1 and boot camp 2. For the cardiopulmonary bypass objective structured assessment of technical skill, the maximum score was 35 points based on a maximum of 5 points in 7 domains. During the analysis of boot camp 1, overall performance a power of $93.2 \%$ at the $5 \%$ significance level using a 2 -tailed test was achieved for detecting a 4-point improvement in overall score. The analysis of boot camp 2 had a power of $60.7 \%$ at the $5 \%$ significance level for detecting this difference. In terms of analyzing individual skills, preparation and commencement are used as examples because they demonstrate domains in which the analysis of boot camp 2 did and did not reject the null hypothesis, respectively. The analysis of boot camp 1 rejected the null hypothesis in all individual domains. As previously outlined, this could be because the courses varied in utility but Table E1 suggests it may also be due to differences in power. In individual domains the maximum score is 5 . For detecting a 1-point difference in an individual domain, all analyses had acceptable power; however, for smaller differences the analysis of individual skills becomes quickly underpowered. The power of the analysis for detecting differences in individual domains will also vary according to the variance within that domain, which explains the differences in the power of the analysis between the preparation and commencement domains. Overall, Table E1 shows that it is possible that differences in power could be part of the explanation as for why the analysis of boot camp 1 and boot camp 2 courses gave different results in relation to performance of cardiopulmonary bypass. Table E1 also demonstrates that our analysis had sufficient power to detect important improvements in performance. 
TABLE E1. Retrospective power calculations at the $5 \%$ significance level based on the standard deviations in our sample

\begin{tabular}{|c|c|c|c|c|c|c|c|}
\hline \multicolumn{8}{|c|}{ Cardiopulmonary bypass } \\
\hline & & & \multicolumn{5}{|c|}{ Individual skills } \\
\hline \multicolumn{3}{|c|}{ Overall performance } & & \multicolumn{2}{|c|}{ Preparation } & \multicolumn{2}{|c|}{ Commencement } \\
\hline Difference & $\begin{array}{c}\text { Boot camp } 1 \\
(\mathrm{n}=15), P \text { value }\end{array}$ & $\begin{array}{c}\text { Boot camp } 2 \\
(\mathrm{n}=8), P \text { value }\end{array}$ & Difference, $P$ value & $\begin{array}{c}\text { Boot camp } 1 \\
(\mathrm{n}=15), P \text { value }\end{array}$ & $\begin{array}{c}\text { Boot camp } 2 \\
(\mathrm{n}=8), P \text { value }\end{array}$ & $\begin{array}{c}\text { Boot camp } 1 \\
(\mathrm{n}=15), P \text { value }\end{array}$ & $\begin{array}{c}\text { Boot camp } 2 \\
(\mathrm{n}=8), P \text { value }\end{array}$ \\
\hline 2 & .409 & .203 & .25 & .281 & .140 & .130 & .107 \\
\hline 3 & .736 & .390 & .50 & .785 & .408 & .375 & .282 \\
\hline 4 & .932 & .607 & .75 & .984 & .731 & .690 & .541 \\
\hline 5 & .991 & .794 & 1.00 & 1.000 & .927 & .905 & .781 \\
\hline 6 & 1.000 & .914 & 1.25 & 1.000 & .989 & .983 & .926 \\
\hline 7 & 1.000 & .971 & 1.50 & 1.000 & .999 & .988 & .982 \\
\hline
\end{tabular}

Analyses were performed in Minitab 17 Statistical Software (State College, Pa) based on paired $t$ test. 